\title{
Krugman on the Malaise of Modern Macro: Critique Without Alternative
}

\author{
KEITH RANKIN ${ }^{1}$
}

Paul Krugman (2009a) argues that the global financial crisis represents a collective failure of an economics profession which had become complacent, believing that financial markets therefore could not, in themselves, cause nontrivial recessions.

Krugman argues cogently — though not without hyperbole - of economists' blindness to sources of instability arising from within financial markets. While economists have failed to meet their own scientific criteria - to assemble a body of knowledge that may be used to make important predictions - Krugman observes 'freshwater' macroeconomists unable to engage fruitfully with their 'saltwater' critics such as himself. This touches a philosophical division idealism versus realism - that goes back as far as Plato and Aristotle.

A profession that retreats into sects that disparage each other has to be a less efficient producer of knowledge than it might otherwise be. Nevertheless, contestability of ideas - albeit with insults - is a better knowledge factory than complacency. The essence of the problem, Krugman believes, is the bankruptcy of the foundation that both 'freshwater' and 'saltwater' had come to accept; the efficient-markets hypothesis.

Krugman sees the seductive mathematical attraction of the neoclassical synthesis - especially in its modern financial form, the efficient-markets hypothesis - as the discipline's Achilles heel. Financial economists want to believe in efficient markets because they are beautiful. Further, the attraction of the hypothesis expanded because, by generating a critical mass of the faithful, it offered lucrative career opportunities. Beauty and money are an attractive combination in matters of career choice as well as in marriage partners. Not only was this kind of economics 'elegant, convenient and lucrative', but it appeared to be empirically validated, at least in as much as it predicted the prices of financial assets relative to each other.

1 Unitec Institute of Technology, krankin@unitec.ac.nz. 
The seductive beauty of the synthesis of Robert Lucas' new classical economics with Eugene Fama's theory of efficient markets is based on the elegance of the price mechanism in ensuring: that unperturbed markets always clear in the short long-run; that the ensuing price signals lead rational buyers and sellers to allocate resources efficiently; that efficient financial markets rule out substantial economic shocks from the financial sector; and that macro-economic imbalances self-adjust in the face of a consistent and credible monetary policy. This appeared to be the solution to the holy grail of macroeconomics; deriving a set of macro-truths from micro-foundations.

Nevertheless, beauty is not substance, as Krugman notes. Krugman eschews the whole idea of drawing useful real-world knowledge from an elegant deductivist model drawn from a set of plausible premises about human behaviour. In reality, economic man falls between the narrow rationality upon which the failed theories depended and irrationality, Krugman argues. This means that economists can make some useful predictive statements, especially by incorporating the insights of behavioural finance, and by pursuing regulatory policies that counter the collectively adverse consequences of much financial decision-making.

Buyers and sellers might not be 'rational' in the sense that neoclassical economists use that term. Behavioural economics shows that people are less calculating than the models assume (or at least they seek to minimise calculation costs). Further, those who do calculate commonly miscalculate. We have biases hard-wired into our pre-historical brains that lead us, for example, to naïvely follow the herd, to avert losses by not selling assets they paid too much for if that means reducing the price, and to accumulate claims to wealth as if they were actual stores of food or other durable goods. But Krugman falls for the latter misapprehension when he says, 'US households have seen \$13 trillion in wealth evaporate.' A \$13 trillion financial bubble never was $\$ 13$ trillion of tangible wealth.

Thus while Krugman touches on important issues he remains far from producing an alternative analysis. He offers insights into a deeper critique of the new classical model, but is unable to extend his message beyond the combined insights of Keynes, and the findings of the new behavioural economists. So, irrational practices in the financial sector - including 'institutions that run amok' - become Krugman's bogey. This is consistent with the banks having become the miscreant of populist analysis, and the view that substantially greater regulation of financial institutions will save us from future events as serious as (or worse than) 2008.

My reflection suggests to me that the neoclassical emphasis on the price mechanism - with its implicit Platonist idealism - is not as central to the workings of free-market capitalism as most economists, including Krugman, believe. There continue to be elegant pathways within the free-market tradition 
that have been little traversed. I do not believe that Krugman has the necessary vision to overturn the efficient-markets hypothesis by exploring such a new pathway.

In some markets, prices rise or fall in the short run but are restored in the long run at greater or lesser quantities bought and sold; the neoclassical theory of the firm. It's not clear that price variation was necessary to achieve such resource reallocations. In other markets, such as housing, the opposite would appear to be true; when demand falls, quantity adjustment predominates in the short run. Price-adjustment is rapid in most financial markets; but the mechanism is far from efficient; it repeatedly over- and under-shoots. Other markets for new durable goods - seem to self-correct with a minimal role for price signalling. The ubiquity of belief in the price mechanism does not necessarily make that mechanism an exclusive micro-foundation for macroeconomics. When addressing economic crises, 'freshwater' critics of Krugman (for example, Mulligan 2009) continue their reluctance to look beyond distortions in relative prices. Despite a substantial growth of inequality preceding recent panics, such economists continue to claim that wages are too high.

An important part of the problem as I see it is our failure to persevere with circular-flow models — the 1950s' 'hydraulic Keynesianism' of Bill Philips notwithstanding ${ }^{2}$ - and to integrate them with balance-of-payments analyses. Krugman himself noted: As a sheer matter of accounting, the balance of payments always balances...A country that runs a surplus on capital account must run a deficit on current account' (2009b: 43). Insights gleaned from the classical critique of mercantilism can enhance our understanding of economic decision-making at the micro level.

While Krugman's historical point of reference is the 1930s' Great Depression, he barely acknowledges that this was an international event, and (Krugman 2009a) likewise fails to globalise his perspective on the 2008 crisis. ${ }^{3}$ As Krugman notes, it is not really credible anymore to claim that better US monetary policies in 1929-31 could have prevented the Great Depression. Nor is it credible that we can claim any global financial crisis is just a domestic crisis that overspilt the Unites States' borders.

The most plausible explanations of the Great Depression - developed, for example, by Eichengreen (1992) — stem from balance-of-payments analysis. It was the refusal of creditor countries to run trade deficits in the context of

2 Indeed Bill Philips is better known for his Philips Curve, in which the changing price of labour plays a key determining role, than for the hydraulic Moniac machines he built in the 1950s, through which he simulated many of the variations of the circular-flow processes. [I first encountered the delightful expression 'hydraulic Keynsianism' in Alex Millmow's (2007) essay on Douglas Copland. Needless to say, Copland, though with Keynesian sympathies, was not a hydraulic Keynesian.]

3 Krugman (2009b) offers a more globally oriented account. 
the restored gold-standard currency regime that prevented debtor countries from running surpluses. (We might note that a system of floating interest rates - adopted from the 1970s as a price-based global stabilisation mechanism - probably could not have prevented the Great Depression. Financial flows between nations negate the requisite exchange-rate adjustments. Indeed, in the 2000s under floating rates, it was the debtor/deficit countries that consistently had appreciating currencies.)

Economic historians have documented the mercantilist world of the sixteenth to eighteenth centuries, and the writings that supported national strategies of producing ongoing current-account surpluses. The mercantilist mindset has never disappeared - it is commonplace among Krugman's 'policy entrepreneurs' (MacFarquhar 2010). Indeed the parable of the failed baby-sitting circle he cites (as a model recession) might be interpreted as a mercantilist system in miniature. Contrary to Krugman, the printing of the correct amount of scrip might not have been a sufficient solution to the problem.

Ask yourself: what happens to microeconomics if our individual actors are hard-wired ${ }^{4}$ to operate according to the same form of rationality as mercantilist governments did (and continue to do)? Such behavioural assumptions could give a new micro-foundational explanation of macroeconomic instability. Combine this with Keynes' insights into the importance of the liquidity constraint and we see a macroeconomic order that periodically veers from over-consumption (the predominant bias in a period in which bank lending expands because bank deposits form an increasing percentage share of the money supply) to underconsumption.

A tendency towards under-consumption (deriving from habitual saving as per the mercantilist mindset) in the 2000s was offset by the marketing by financial intermediaries of secured and unsecured debt to households; an enterprise global in scale. This offset was strong enough in most of the decade to maintain high rates of consumer-led economic growth. (Inflation only threatened in 2007 as demand for food and oil outstripped supply.) The price of maintaining aggregate demand though increasingly unsustainable household debt was the creation of a huge bubble of financial claims on households and countries that had to consume more than they produced in order to accommodate those savers who habitually produced more than they consumed.

4 Hard-wiring to store and conserve food - like the squirrel of folklore - and other life-preserving items must have been an important facet of human evolution. That saving bias has been transferred from storing actual wealth to storing claims on wealth, and indeed 'claims on claims' (as Krugman calls derivatives). 
A second periodic over-consumptionist bias is revealed by a careful inspection of the basic circular-flow model. The link labelled 'household saving' is actually a netting of four separable flows: 'Saving' = gross saving - expenditure funded by past saving - lending to households + loan repayments by households.

Net saving can easily become negative when expenditure funded by past saving occurs in unusually high quantities - due either to panic, population ageing, or simply the sheer bulk of financial assets in circulation. What happens if there is an unsustainable surge to realise historical claims as expenditure on goods and services? This - a crisis of over-consumption - is likely to be the nature of the biggest macroeconomic crisis this century, and we have no clear precedent for it. By developing the circular-flow approach, we can both explain the recessionary events at the end of the 2000s, and predict the quite different events that can be expected this century when the great pension funds are unleashed upon a supply-inelastic global economy.

To summarise: Paul Krugman is right to question the capability of economics developed under the auspices of the dominant neoclassical paradigm to predict business cycle events. A more constructive critique is required, however. The approach suggested here, which changes the analysis of markets away from its neoclassical emphasis on relative prices, may give many of the additional insights that we will require if we are to navigate the new global environment successfully. The new circumstances include heightened inequalities (especially within developed nations) and indications that the global economy as a whole may be much less supply-elastic — due to both natural and human resource constraints - than it proved to be last century.

\section{References}

Eichengreen, B. 1992, Golden Fetters. The Gold Standard and the Great Depression 1919-1939, New York: Oxford University Press.

MacFarquhar, Larissa 2010, 'The Deflationist', New Yorker, 1 March.

Millmow, Alex 2007, 'Douglas Copland' in A Biographical Dictionary of Australian and New Zealand Economists, J. E. King (ed.), Edward Elgar: Cheltenham (UK).

Krugman, Paul 2009a, 'How Did Economists Get It So Wrong?' New York Times, 6 September.

Krugman, Paul 2009b, The Return of Depression Economics and the Crisis of 2008, New York: Norton. 
Agenda, Volume 17, Number 1, 2010

Mulligan, Casey 2009, 'Is Macroeconomics Off Track?' The Economists' Voice $6(10)$.

RBNZ 2007, 'Introducing the MONIAC — an early and innovative economic model'. Available at: http://www.rbnz.govt.nz/research/search/article. asp?id=4006. 